\title{
The negative effects of exogenous DNA binding on porcine spermatozoa are caused by removal of seminal fluid
}

\author{
J.H. Kang ${ }^{\text {a }}$, H. Hakimov ${ }^{\text {a }}$, A. Ruiz ${ }^{\text {, R.M. Friendship }}{ }^{\text {, }}$, \\ M. Buhr ${ }^{a}$, S.P. Golovan ${ }^{a, *}$ \\ "Department of Animal and Poultry Science, University of Guelph, Guelph, ON, Canada NIG 2WI \\ ${ }^{b}$ Department of Population Medicine, University of Guelph, Guelph, ON, Canada N1G 2 WI
}

\begin{abstract}
Sperm-mediated gene transfer (SMGT) might become the most efficient and cost effective technique to generate transgenic animals, which will significantly increase their application in biomedical research and in commercial production. Despite some successes, the technique has remained controversial for almost 20 years and despite number of studies the reasons for poor reproducibility of this promising technology has not been understood. We suggest that the reason for poor reproducibility is the presence of natural defences against exogenous DNA invasion acting in spermatozoa or in embryo. Based on previous reports we have investigated the effect of foreign DNA binding on spermatozoa by monitoring motility, viability and genomic DNA damage. Evaluation of DNA binding in sperm collected from 16 boars demonstrated that $28-45 \%$ of the added pEGFP plasmid was bound to spermatozoa with $9-32 \%$ being internalized in sperm nucleus. In agreement with previous reports, our results demonstrated that the pEGFP-treated sperm show an average a 2-fold decrease in motility $(p<0.05), 5$-fold decrease in progressive motility $(p<0.05)$, and 1.4-fold increase in number of sperm with highly damaged DNA $(p<0.05)$ as detected by Comet assay. In contrast with previous reports, we demonstrate that all such changes were associated with the removal of seminal plasma during the washing step and not with foreign DNA binding per se. We suggest that poor reproducibility of SMGT most likely result from selection against DNA-loaded sperm at later stages of fertilization.
\end{abstract}

Keywords: Sperm-mediated gene transfer; Comet assay; Spermatozoa; DNA damage; Seminal plasma

\section{Introduction}

Sperm-mediated gene transfer (SMGT) uses sperm as a natural vector to transfer transgenes [1]. SMGT would provide the cheapest and most efficient method to produce large transgenic animals [2-5]. Despite the apparent simplicity of the method, many previous

\footnotetext{
* Corresponding author at: University of Guelph, Centre for Genetic Improvement of Livestock, Department of Animal and Poultry Science, 50 Stone Road East, Guelph, ON, Canada N1G 2 W1. Tel.: +1 519824 4120x56281; fax: +1 5198369873 .

E-mail address: sgolovan@uoguelph.ca (S.P. Golovan).
}

attempts to confirm SMGT efficiency have not achieved the desired result. Several groups tried to replicate the initial mouse results but unsuccessfully. Most notably Brinster et al. [6] tested 1300 offspring produced by SMGT but none of them were transgenic. Similarly, high efficiency of linker-based SMGT [4] or restriction enzyme-mediated SMGT [2] have not been reproduced to our knowledge in other laboratories. Since initial demonstration of DNA binding to rabbit sperm [7], many researchers have shown that DNA binding is a natural ability of sperm in many species [8]. Such ability would have major evolutionary implications and begs a question of how organisms protect their germline 
from invasion by exogenous DNA under natural conditions. It has been reported that incubation with exogenous DNA led to the activation of sperm nucleases [9-11] and a significant decrease in sperm motility $[12,13]$. Both sperm immobilization and nuclease activation might indicate the presence of natural defences activated in the sperm after the binding of exogenous DNA. It is reasonable to suggest that poor reproducibility of SMGT might also be related with activation of such defences in sperm.

The objective of our project was to investigate the effect of foreign DNA binding on spermatozoa by monitoring DNA binding and internalization, motility, viability and genomic DNA damage. Better understanding of foreign DNA effects on sperm will allow researchers to significantly improve SMGT reproducibility and better understand natural defences against foreign DNA invasion.

\section{Materials and methods}

\subsection{Animals and handling}

Eighteen sexually mature Yorkshire boars were kept at the Ponsonby Research Station, University of Guelph. Each boar was housed individually according to the guidelines of Canadian Council of Animal Care. All animal manipulations were approved by the University of Guelph Animal Care Committee.

\subsection{Semen collection and preparation}

Once per week, collection of sperm was performed by the gloved hand methods. Washed and DNA-treated semen was prepared as described previously [3,21]. Swine fertilization medium [SFM; $1 \mathrm{~L}$ contains $11.25 \mathrm{~g}$ glucose, $10 \mathrm{~g}$ sodium citrate $\left(2 \mathrm{H}_{2} \mathrm{O}\right), 4.7 \mathrm{~g}$ EDTA $\left(2 \mathrm{H}_{2} \mathrm{O}\right), 3.25 \mathrm{~g}$ citric acid $\left(\mathrm{H}_{2} \mathrm{O}\right), 6.5 \mathrm{~g}$ Trizma adjusted to $\mathrm{pH} 7.4$ ] supplemented with $6 \mathrm{mg} / \mathrm{mL}$ BSA (Fisher) was used as an extender [3]. To prepare seminal plasma, the supernatant was saved and centrifuged again. This saved seminal plasma was added back to the washed or DNA-treated sperm from the same boar to achieve a final concentration similar to the negative control.

\subsection{Sperm motility and viability}

Semen was prepared at a concentration of $10^{7}$ spermatozoa/mL for motility and viability evaluation. Motility was measured by using computer-assisted semen analysis (CASA) (Spermvision, Minitube).
Prepared samples were pre-warmed for $20 \mathrm{~min}$ before evaluation and $2 \mu \mathrm{L}$ of sample was loaded into 4chamber slide (Leja, Nieuw-Venner, Netherlands). In this study, sperm was considered motile if both velocity average path (VAP) was $>20 \mu \mathrm{m} \mathrm{s}^{-1}$ and velocity curvilinear (VCL) $>5 \mu \mathrm{m} \mathrm{s}^{-1}$ and progressively motile as those cells with VAP $>45 \mu \mathrm{m} \mathrm{s}^{-1}$ or straightness $>45 \%$ [14].

Dual fluorescent PI/SYBR 14 staining (LIVE/ DEAD $^{(B)}$ Sperm Viability Kit, Invitrogen) was used to evaluate viability of sperm according to manufacturer's protocol. The number of red (dead) and green cells (live) in a total of 100 sperm was counted in duplicate for each sample with a fluorescent microscope (LEICA DMR, Germany) with the filter (450-490 nm excitation wavelengths) at $400 \times$ magnification. Viability was expressed as the average percentage of viable sperm cells from 100 counted sperm cells.

\subsection{Assessment of DNA binding}

A pEGFP-N1 vector containing Green Fluorescent protein reporter gene under control of CMV promoter was used for this study (BD Biosciences, Mississauga, Canada). Plasmids were extracted using Plasmid Mega Kit (Qiagen). The StuI restriction enzyme (Invitrogen, Burlington, Canada) was used to prepare linearized plasmid and digestion efficiency was checked by $1 \%$ agarose gel electrophoresis. Scintillation counting was used to assess DNA binding of sperm. The digested pEGFP-N1 was labelled with $\left[\alpha-{ }^{32} \mathrm{P}\right]$ dCTP using Nick Translation Kit (Invitrogen, Burlington, Canada). Spermatozoa $\left(10^{6}\right.$ cells) were incubated with $0.4 \mu \mathrm{g}$ of pEGFP-N1 and washed twice before quantification. Radioactivity in supernatant and pellet was analyzed in a liquid scintillation counter (Model LS6000SC, Beckman, Fullerton, CA, USA).

\subsection{DNA extraction from whole sperm and sperm nuclei}

Sperm genomic DNA extraction was performed using phenol:chloroform. Briefly, a sperm pellet was suspended with $100 \mu \mathrm{L}$ of PBS and $400 \mu \mathrm{L}$ of sperm extraction solution ( $2 \% \quad \beta$-mercaptoethanol, $10 \mathrm{mM}$ Tris pH 8.0, $100 \mathrm{mM} \mathrm{NaCl}, 0.5 \%$ SDS and $10 \mathrm{mM}$ EDTA) was added and incubated for $30 \mathrm{~min}$ at $55^{\circ} \mathrm{C}$. After that $20 \mu \mathrm{L}$ of proteinase K $(20 \mathrm{mg} / \mathrm{mL}$, Sigma) was added and incubated at $55^{\circ} \mathrm{C}$ overnight. For extraction, $500 \mu \mathrm{L}$ of phenol:chloroform (Sigma) was added, briefly vortexed and centrifuged at 13,500 $\times g$ for $5 \mathrm{~min}$. DNA precipitation was performed with 2 
volumes of $100 \%$ ethanol and the pellet was washed with $70 \%$ ethanol, dried and dissolved in $200 \mu \mathrm{L}$ of water.

For nuclei extraction, the sperm pellet was resuspended in $100 \mu \mathrm{L}$ of PBS and $100 \mu \mathrm{L}$ of DTT buffer (0.1 M DTT, $0.05 \mathrm{M}$ Tris, $\mathrm{pH} 7.5$ ) was added and incubated for $30 \mathrm{~min}$ on ice. Then, $800 \mu \mathrm{L}$ of CTAB buffer (10\% CTAB, $0.01 \mathrm{M}$ DTT) was added to the sample and incubated again for $60 \mathrm{~min}$ on ice. The recovered sperm nuclei were washed twice in $50 \mathrm{mM}$ Tris, pH 8.0 and centrifuged at $10,000 \times g$ for $5 \mathrm{~min}$. The sperm genomic DNA extraction was performed as mentioned above using phenol:chloroform. The concentration of DNA samples was measured with Picogreen dsDNA Quantification Kit (Molecular Probes, Inc., Eugene, OR) and used as a template for Real-Time PCR.

\subsection{Real-Time PCR quantification}

Primer sets were designed using Primer 3 (http:// www.frodo.wi.mit.edu/cgi-bin/primer3/primer3_www .cgi). In order to accurately quantify different samples, one has to ensure that the same amount of sperm DNA was used in each Real-Time PCR. The amount of DNA used in PCR was normalized for technical variability using SINE repetitive sequences [14].

Following primers were used: SINE (GGATCCGGCATTGCCGTTAG, GTCTTTTTTTGCCATTTCTTGG) and GFP (TATATCATGGCCGACAAGCA, GAACTCCAGCAGGACCATGT). Platinum ${ }^{(B)}$ SYBR $^{\left({ }^{(B)}\right.}$ Green qPCR SuperMix-UDG with ROX (Invitrogen) was used for Real-Time PCR quantification reaction using ABI 7700 Real Time machine. The amplification of the correct product was monitored by the melting curve during PCR, running products on agarose gel after PCR and sequencing. The standard curve method was used for quantification of pEGFP plasmid $[15,16]$.

\subsection{Comet assay}

Comet assay was performed as described previously with some modifications [17,18]. Collected and washed semen was diluted to a concentration of $5 \times 10^{6}$ spermatozoa $/ \mathrm{mL}$. The pellet was resuspended in $98 \mu \mathrm{L}$ of PBS, mixed with $2 \mu \mathrm{L}$ of $2 \% \beta$ mercaptoethanol and incubated for $1 \mathrm{~h}$ at $4{ }^{\circ} \mathrm{C}$. Cells were further mixed with $200 \mu \mathrm{L}$ of lysis buffer $(1.25 \mathrm{M}$ $\mathrm{NaCl}, 0.01 \%$ sodium $N$-lauroyl sarcosine, $50 \mathrm{mM}$ sodium salt of EDTA, $100 \mathrm{mM}$ Tris- $\mathrm{HCl}, \mathrm{pH} \mathrm{10}$ ) and incubated for $2 \mathrm{~h}$ at $4{ }^{\circ} \mathrm{C}$. Sperm were centrifuged at
$1500 \times g$ for $5 \mathrm{~min}$ to remove lysis buffer and $200 \mu \mathrm{L}$ of incubation buffer (50 mM Tris- $\mathrm{HCl}, \mathrm{pH} 8.0,10 \mathrm{mM}$ EDTA) was added. After $1 \mathrm{~h}$ incubation at $37^{\circ} \mathrm{C}$, $12.5 \mu \mathrm{L}$ of proteinase $\mathrm{K}(50 \mathrm{mg} / \mathrm{mL})$ were added and samples were incubated overnight at $55^{\circ} \mathrm{C}$. For the treated sperm sample, the diluted sample $(65 \mu \mathrm{l})$ was mixed with $65 \mu \mathrm{L}$ of $1 \%$ of low melting agarose (Sigma-Aldrich) pre-warmed at $55^{\circ} \mathrm{C} .50 \mu \mathrm{L}$ of this mixture were loaded onto a microgel slide pre-coated with $1 \%$ normal agarose. Then $50 \mu \mathrm{L}$ of $0.5 \%$ of low melting agarose gel was poured as a 3 rd layer to protect the sample layer. The slides went through an unwinding step for $25 \mathrm{~min}$ in fresh alkaline electrophoresis buffer ( $300 \mathrm{mM}$ sodium hydroxide, $1 \mathrm{mM}$ EDTA, 0.2\% DMSO, 0.1\% 8-hydroxyquinoline, $\mathrm{pH}$ $>13$ ) in horizontal electrophoresis unit and electrophoresed in fresh alkaline electrophoresis buffer for $20 \mathrm{~min}$ at $20 \mathrm{~V}$. After electrophoresis slides were immersed three times in $0.4 \mathrm{M}$ Tris- $\mathrm{HCl}, \mathrm{pH} 7.4$ for neutralization and finally immersed into $70 \%$ of ethanol and completely dried. Slides were stained with $500 \mu \mathrm{L}$ of 10,000 times dilution of SYBR Gold Nucleic Acid Gel Stain (Molecular Probes Company) for $10 \mathrm{~min}$. To quantify the amount of sperm genomic DNA damage, five classes from zero to four were used $[19,20]$.

\subsection{Statistical analysis}

All data are reported as the mean of three independent replications. Analysis of variance (ANOVA) among the groups was tested and their interactions were analyzed by GLM using Tukey test. The experimental design was a randomized completed block (RCB) design, in which the blocks were boars. A $p$-value less than 0.05 was considered significant and between $0.05<p<0.1$ as a tendency in all experiments.

\section{Results}

\subsection{Binding and internalization of $p E G F P-N 1$ plasmid by porcine sperm}

To evaluate DNA binding in our research pig population a total of 3 ejaculates were collected from 16 boars and thoroughly washed to remove seminal plasma which contains inhibitors of DNA binding $[10,22]$. DNA binding was evaluated by incubation of sperm with ${ }^{32}$ P-labelled linearized pEGFP-N1 and any unbound plasmid was removed by two washing steps. DNA binding rates varied from $28 \%$ to $45 \%$ of the 


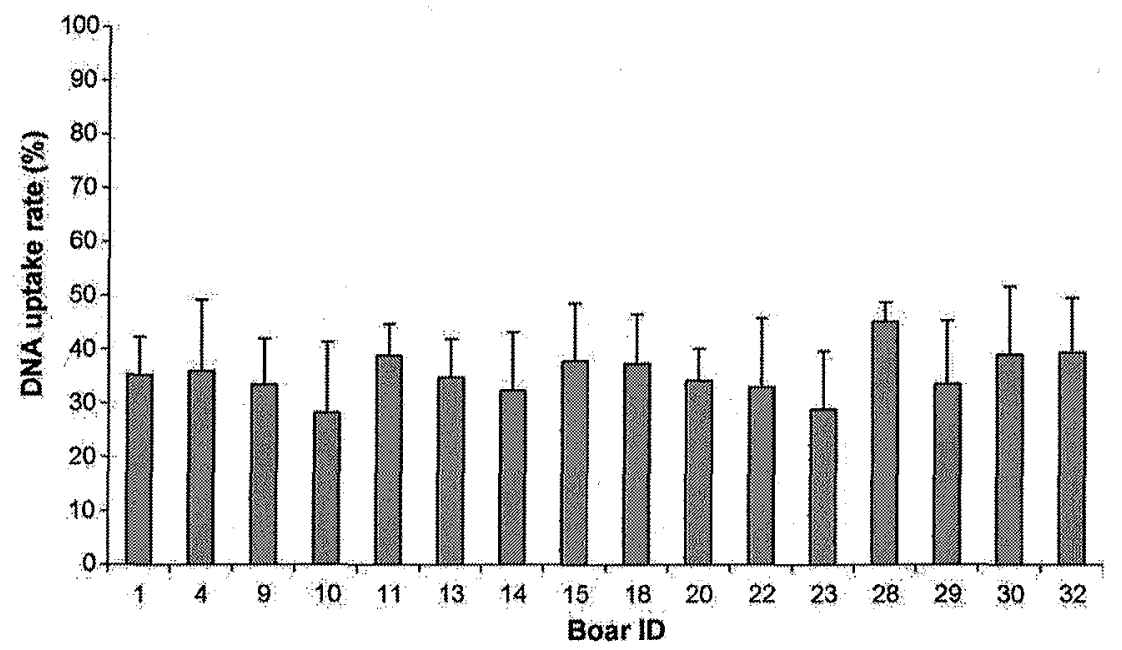

Fig. 1. DNA binding rate (\%) by porcine sperm. No significant differences were detected among boars $(p=0.86)$ (mean \pm S.D., $N=3$ ejaculations $/$ boar).

added DNA (Fig. 1). No significant differences were detected between boars in DNA binding.

To determine what percentage of bound pEGFP was internalized into the sperm nuclei, quantification by Real-Time PCR was developed. To quantify the amount of pEGFP all DNA (membrane bound and internalized in the nucleus) was extracted from sperm incubated with the plasmid. To quantify pEGFP internalized in the nucleus, DNA was extracted from purified sperm nuclei. Internalization rate in the sperm nucleus varied from $8.6 \%$ to $31.5 \%$ of total bound pEGFP, but no significant differences were detected between the boars (Fig. 2).

\subsection{Effect of DNA binding on sperm motility}

To evaluate the effect of exogenous DNA binding on sperm motility, the spermatozoa were evaluated before and after incubation with pEGFP. It was found that while untreated sperm showed normal motility, the pEGFP-treated sperm showed on average a 2-fold decrease in motility and a 5 -fold decrease in progressive motility $(p<0.05)$ (Fig. 3). To identify the cause for decreased motility the effect of different sperm treatments was further tested with three boars. It was found that motility and progressive motility was again drastically decreased after incubation with DNA

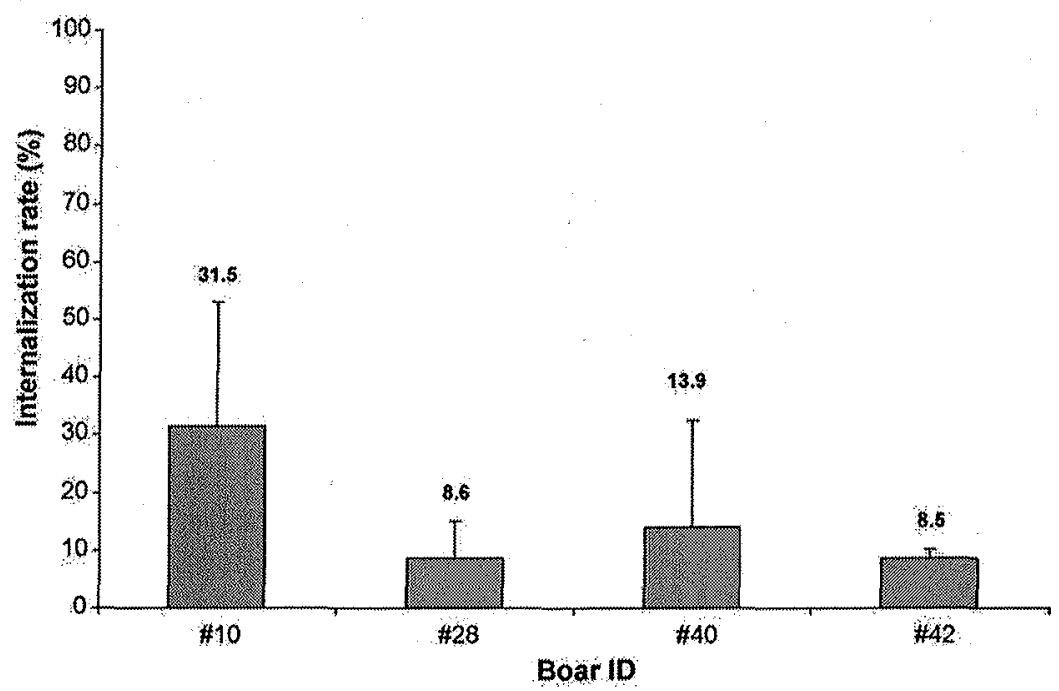

Fig. 2. Internalization rate of sperm-bound pEGFP-N1 into nucleus as detected by Real-Time PCR. No significant differences among boars were detected ( $p=0.2$ ) (mean \pm S.D.; $N=3$ ejaculations/boar). 

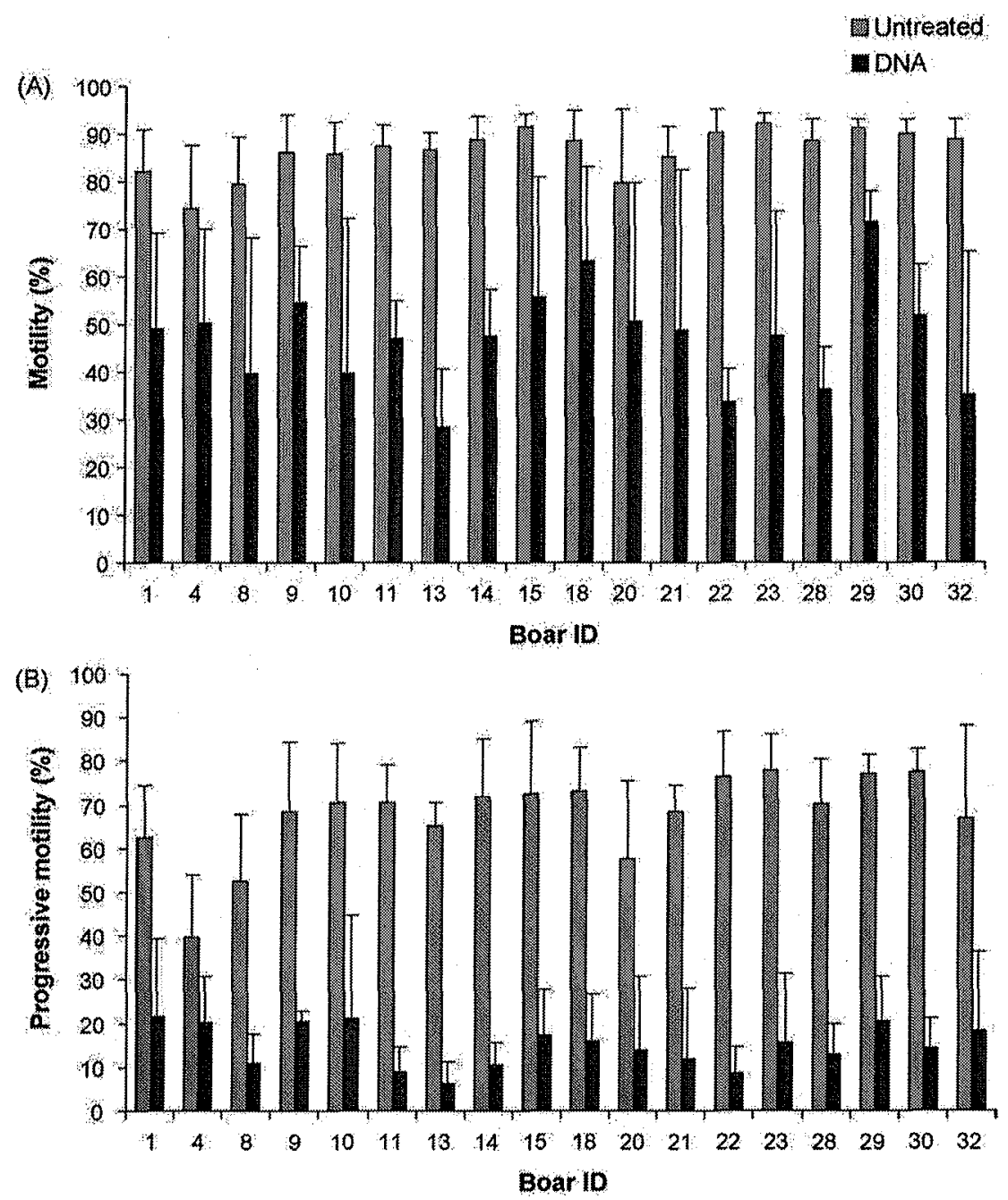

Fig. 3. Effect of DNA incubation on (A) sperm motility and (B) progressive motility. Untreated: no treatment; DNA: sperm was washed and incubated with pEGFP. Significant difference between control and treatment was found for all boars in (A) and (B) (Tukey test; $p<0.05$ ).

$(p<0.05)$. At the same time there was a similar decrease in motility after the washing step (Fig. 4). There was no additional decrease of sperm motility after pEGFP incubation $(p>0.05)$. Thus, the washing step alone seems to cause a decrease in sperm motility and not the incubation with pEGFP. Addition of seminal plasma after washing returned sperm motility to normal in both washed and pEGFP-treated samples (Fig. 4). Therefore, the removal of seminal plasma led to the decrease in sperm motility.

\subsection{Damage of sperm DNA}

Alkaline Comet assay is a sensitive technique for detection of DNA damage at a single cell level [17], and was used to detect damage in sperm incubated with
pEGFP. Data from three boars indicates that both sperm washing $(125 \%, p<0.001)$ and DNA treatment $(135 \%$, $p<0.0001$ ) resulted in an increase in the number of sperm with highly damaged DNA compared to control $(100 \%)$ (not shown). At the same time, there were no differences in the DNA damage between washed and DNA-treated groups $(p=0.14)$. Therefore, it might be concluded that the washing step was primarily responsible for increased DNA damage detected in sperm genomic DNA.

Sperm viability was determined for all boars by measuring plasma membrane integrity using PI/SYBR 14 staining [23]. Viability after $24 \mathrm{~h}$ incubation with pEGFP varied from $63.3 \%$ to $78.5 \%$ with no differences between boars $(p>0.05)$ (not shown). In addition, the effect of each treatment including washing and 

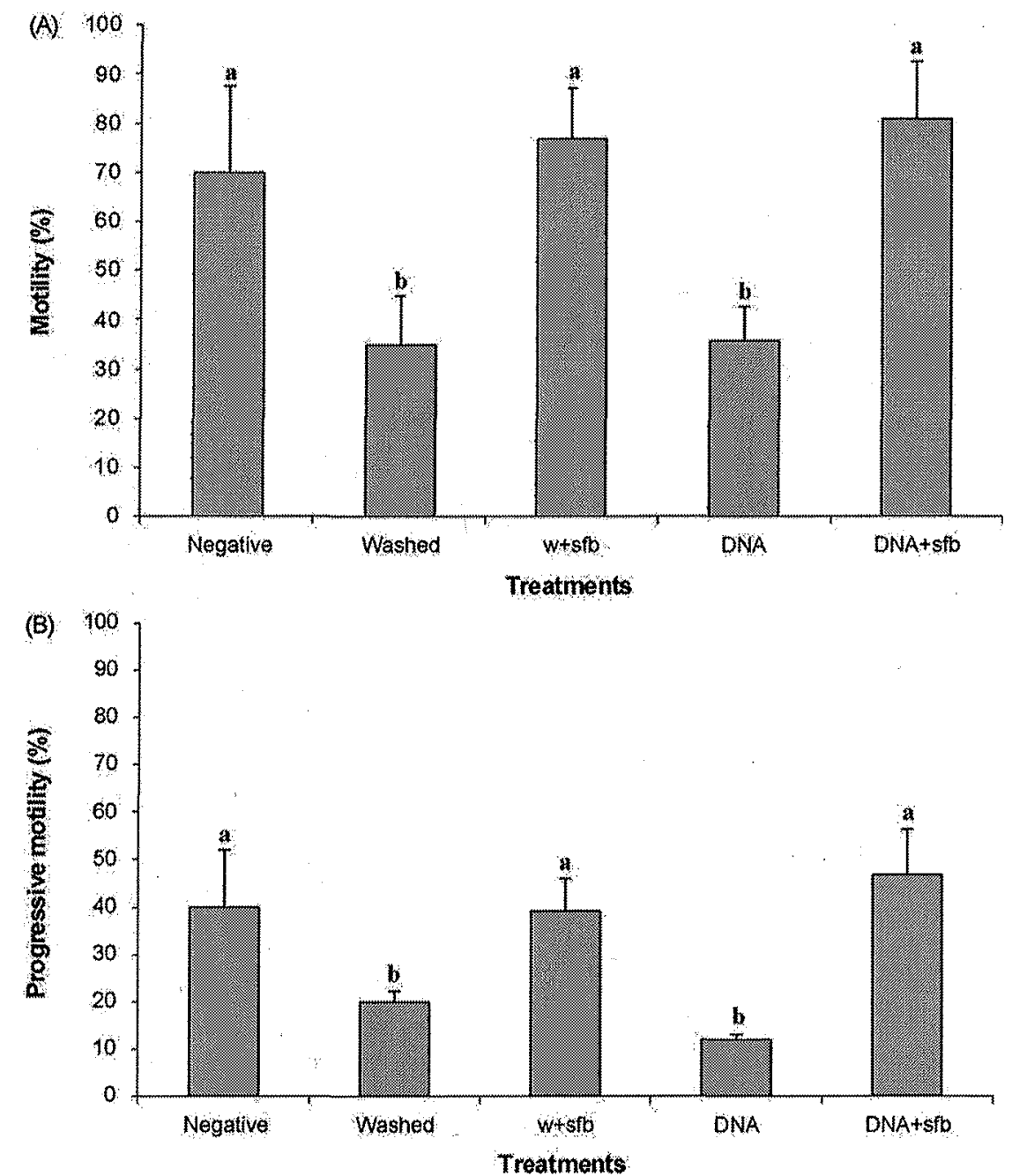

Fig. 4. Evaluation of effect of DNA treatment on (A) sperm motility and (B) progressive motility. Negative: no treatment; washed: sperm was washed; $w+$ sfb: sperm was washed and seminal plasma added back; DNA: sperm was washed and incubated with pEGFP; and DNA + sfb: sperm was washed, seminal plasma was added back and sperm was incubated with pEGFP (mean \pm S.D., $N=3$ boars, 3 ejaculations/boar). Different letters $(a, b)$ indicate significant difference (Tukey test, $p<0.05$ ).

incubation with pEGFP was evaluated with sperm from three boars. The results show no differences in sperm viability among the untreated, washed, and pEGFPtreated sperm $(p>0.05)$ (not shown).

\section{Discussion}

In our previous testing of SMGT 105 fertilized embryos $(\geq 2$ cells) were produced by 18 sows inseminated with pEGFP-treated sperm from 3 different boars. Neither GFP expression nor presence of pEGFP plasmid by PCR was detected in tested embryos (not shown). It was important to confirm that in our experiment porcine sperm could bind and internalize plasmid DNA. Evaluation of DNA binding in sperm collected from 16 boars demonstrated that $28-45 \%$ of the added pEGFP plasmid was bound to spermatozoa with $9-32 \%$ being internalized in sperm nucleus with no significant differences between boars. In contrast, considerable differences were reported in the ability of porcine sperm to bind exogenous DNA between different experiments and even between different boars $[21,24]$. To compare our results, we calculated an actual copy number of plasmids internalized per spermatozoa. In our experiment, we estimate that $0.6 \times 10^{4}$ (boar \# 28 ) and $1.4 \times 10^{4}$ (boar \# 10) plasmids were internalized per spermatozoa. This is similar to $1.3 \times 10^{4}$ internalized plasmids achieved by Lavitrano et al. [21] and 16-37-fold more than what was found previously for pigs $\left(3.8 \times 10^{2}\right)$ [24]. While it might be 
possible to increase DNA binding and internalization by using electroporation or lipofection [25], based on our results, it seems unlikely that failures of SMGT can be explained by problems at the DNA/sperm interaction stage. It is known that pronuclear microinjection of around 500 copies of plasmid per egg produces optimal transgenesis results and even injection of just 5 copies is sufficient to produce transgenic mice [26].

Our results demonstrated that the pEGFP-treated sperm show an average a 2-fold significant decrease in motility, 5 -fold decrease in progressive motility, and 1.4-fold increase in number of sperm with highly damaged DNA. Such changes in pEGFP-loaded sperm clearly might negatively affect its ability to participate in fertilization and explain repeated failure of SMGT. High motility of sperm has been always an important indicator for successful fertilization in swine [27]. Selection of donor boars with high percentage of motile sperm is also one of the major criteria for successful SMGT [21]. It has been previously reported that a similar decrease in sperm motility was observed after DNA treatment in porcine [28] and bull spermatozoa $[12,13]$ but no explanation for decreased motility was provided. Before incubation with pEGFP, sperm is repeatedly centrifuged and washed to remove seminal plasma inhibitors of DNA binding. Thus either centrifugation, removal of seminal plasma, or incubation with DNA might have caused the loss of motility. Our results clearly demonstrate that a decrease in the motility of DNA-treated sperm resulted from removal of seminal plasma during sperm washing. Seminal plasma contains many factors that maintain sperm motility, so it is not surprising that its removal decreased sperm motility [29,30]. Similarly, it has been suggested that mature spermatozoa contain nucleases induced by internalization of foreign DNA that might cause degradation of both sperm chromosomal DNA and added exogenous DNA [9-11]. Such DNA degradation might decrease possibility that sperm carrying exogenous DNA will participate in fertilization. For example, it has been previously demonstrated that human cervical mucus can act as a selective sieve preventing progress of spermatozoa with fragmented DNA and chromatin structural abnormalities [31,32]. Even if such sperm reaches the oocyte, it is unlikely to produce viable embryos due to poor implantation and abortion [33]. While a significant increase in sperm genomic DNA damage was detected by the Comet assay in our experiment, once more, it seems that the washing step was primarily responsible for this increase. It is well known that spermatozoa deficiency in nuclear DNA repair systems results in their increased susceptibility to oxidative stress and DNA fragmentation [34]. Seminal plasma is a major source of protective antioxidant activity for spermatozoa and its removal likely increased the production of reactive oxygen species by seminal leukocytes and spermatozoa resulting in increased DNA damage [35].

In conclusion, poor reproducibility of SMGT and evolutionary common sense does suggest presence of natural barriers against sperm carrying exogenous DNA. Despite significant amount of plasmid binding and internalization by porcine sperm similar to reported by Lavitrano et al. [21] we did not detect any major negative effects on sperm motility, viability or DNA damage. A significant decrease in motility and an increase in DNA damage seem to be associated with the washing step alone and do not explain why only spermatozoa not carrying exogenous DNA are able to participate in fertilization. Our results seemingly indicate the absence of specific defences against foreign DNA in spermatozoa, so it is likely such barriers exist at later stages of sperm transport or fertilization. The reproductive tract is designed as an obstacle course for spermatozoa with the number of selection steps at which damaged or fertilization-deficient spermatozoa are eliminated $[36,37]$. This enormous selection pressure decreases the number of participating spermatozoa from $10^{9}$ to just a few actually reaching the oocyte. It seems likely that DNA-loaded sperm are selected against in vivo, and as a result either does not reach the egg, cannot properly participate in fertilization or produce nonviable embryos. Another indication that DNA-loaded sperm might be selected against in vivo is that, unlike SMGT, direct ICSI of DNA-loaded sperm into oocyte has been consistently successful in producing transgenic animals with high efficiency [38-40]. ICSI bypasses many normal selection steps of fertilization, such as sperm interaction with the reproductive tract and oocyte. Further experiments must be performed to understand the transportation of DNA carrying sperm in the reproductive tract in vivo, its ability to participate in the fertilization process and the fate of foreign DNA delivered to oocytes. Better understanding of such natural defences against foreign DNA invasion will allow finally solving long standing SMGT reproducibility problems and permitting wider use of this promising technology to generate transgenic animals for biomedical research and commercial production.

\section{Acknowledgements}

We thank Dr. M. Buhr's laboratory researchers, Dr. Angel De Grau (Minitube) and staff in Ponsonby and Arkell research stations for their help with this project. 
We also thank Margaret Quinton for help with statistical analysis of the results and Adam Colley for his kind assistance with the paper preparation. This work was funded by Ontario Pork, OMAFRA and NSERC CRD program.

\section{References}

[1] Lavitrano M, Camaioni A, Fazio VM, Dolci S, Farace MG, Spadafora C. Sperm cells as vectors for introducing foreign DNA into eggs: genetic transformation of mice. Cell 1989;57: 717-23.

[2] Shemesh M, Gurevich M, Harel-Markowitz E, Benvenisti L, Shore LS, Stram Y. Gene integration into bovine sperm genome and its expression in transgenic offspring. Mol Reprod Dev 2000;56:306-8.

[3] Lavitrano M, Bacci ML, Forni M, Lazzereschi D, Di Stefano C, Fioretti D, et al. Efficient production by sperm-mediated gene transfer of human decay accelerating factor (hDAF) transgenic pigs for xenotransplantation. Proc Natl Acad Sci USA 2002;99:14230-5.

[4] Chang K, Qian J, Jiang M, Liu YH, Wu MC, Chen CD, et al. Effective generation of transgenic pigs and mice by linker based sperm-mediated gene transfer. BMC Biotechnol 2002;2:5.

[5] Webster NL, Forni M, Bacci ML, Giovannoni R, Razzini R, Fantinati $P$, et al. Multi-transgenic pigs expressing three fluorescent proteins produced with high efficiency by sperm mediated gene transfer. Mol Reprod Dev 2005;72:68-76.

[6] Brinster RL, Sandgren EP, Behringer RR, Palmiter RD. No simple solution for making transgenic mice. Cell 1989;59: 239-41.

[7] Brackett BG, Baranska W, Sawicki W, Koprowski H. Uptake of heterologous genome by mammalian spermatozoa and its transfer to ova through fertilization. Proc Natl Acad Sci USA 1971:68:353-7.

[8] Gandolfi F. Sperm-mediated transgenesis. Theriogenology 2000;53:127-37.

[9] Maione B, Pittoggi C, Achene L, Lorenzini R, Spadafora C. Activation of endogenous nucleases in mature sperm cells upon interaction with exogenous DNA. DNA Cell Biol 1997;16: 1087-97.

[10] Spadafora C. Sperm cells and foreign DNA: a controversial relation. Bioessays 1998;20:955-64.

[11] Szczygiel MA, Moisyadi S, Ward WS. Expression of foreign DNA is associated with paternal chromosome degradation in intracytoplasmic sperm injection-mediated transgenesis in the mouse. Biol Reprod 2003;68:1903-10.

[12] Schellander K, Peli J, Schmoll F, Brem G. Artificial insemination in cattle with DNA-treated sperm. Anim Biotechnol 1995;41-50.

[13] Anzar M, Buhr MM. Spontaneous uptake of exogenous DNA by bull spermatozoa. Theriogenology 2006;65:683-90.

[14] Frengen E, Thomsen P, Kristensen T, Kran S, Miller R, Davies W. Porcine SINEs: characterization and use in species-specific amplification. Genomics 1991;10:949-56.

[15] Wong ML, Medrano JF. Real-time PCR for mRNA quantitation. Biotechniques 2005;39:75-85.

[16] Van Raemdonck H, Maes A, Ossieur W, Verthe K, Vercauteren T, Verstraete $W$, et al. Real time PCR quantification in groundwater of the dehalorespiring Desulfitobacterium dichloroeliminans strain DCA11. J Microbiol Methods 2006
[17] Singh NP, Muller CH, Berger RE. Effects of age on DNA doublestrand breaks and apoptosis in human sperm. Fertil Steril 2003;80:1420-30.

[18] Fraser L, Strzezek J. Effects of freezing-thawing on DNA integrity of boar spermatozoa assessed by the neutral comet assay. Reprod Domest Anim 2005;40:530-6.

[19] Anderson D, Yu TW, Phillips BJ, Schmezer P. The effect of various antioxidants and other modifying agents on oxygenradical-generated DNA damage in human lymphocytes in the COMET assay. Mutat Res 1994;307:261-71.

[20] Palus J, Dziubaltowska E, Rydzynski K. DNA damage detected by the comet assay in the white blood cells of workers in a wooden furniture plant. Mutat Res 1999;444:61-74.

[21] Lavitrano M, Forni M, Bacci ML, Di Stefano C, Varzi V, Wang $\mathrm{H}$, et al. Sperm mediated gene transfer in pig: selection of donor boars and optimization of DNA uptake. Mol Reprod Dev 2003;64:284-91.

[22] Zani M, Lavitrano M, French D, Lulli V, Maione B, Sperandio S, et al. The mechanism of binding of exogenous DNA to sperm cells: factors controlling the DNA uptake 2. Exp Cell Res 1995;217:57-64.

[23] Juonala T, Salonen E, Nurttila T, Andersson M. Three fluorescence methods for assessing boar sperm viability. Reprod Domest Anim 1999;34:83-7.

[24] Horan R, Powell R, McQuaid S, Gannon F, Houghton JA. Association of foreign DNA with porcine spermatozoa. Arch Androl 1991;26:83-92

[25] Celebi C, Guillaudeux T, Auvray P, Vallet-Erdtmann V, Jegou B. The making of "transgenic spermatozoa". Biol Reprod 2003;68:1477-83.

[26] Brinster RL, Chen HY, Trumbauer ME, Yagle MK, Palmiter RD. Factors affecting the efficiency of introducing foreign DNA into mice by microinjecting eggs. Proc Natl Acad Sci USA 1985;82:4438-42.

[27] Tardif S, Laforest JP, Cormier N, Bailey JL. The importance of porcine sperm parameters on fertility in vivo. Theriogenology 1999;52:447-59.

[28] Gandolfi F, Terqui M, Modina S, Brevini TA, Ajmone-Marsan P, Foulon-Gauze $F$, et al. Failure to produce transgenic offspring by intra-tubal insemination of gilts with DNA-treated sperm. Reprod Fertil Dev 1996;8:1055-60.

[29] Dyck MK, Gagne D, Ouellet M, Senechal JF, Belanger E, Lacroix D, et al. Seminal vesicle production and secretion of growth hormone into seminal fluid. Nat Biotechnol 1999;17: 1087-90.

[30] Holody D, Strzezek J. Heparin- and $\mathrm{Zn}^{2+}$-binding proteins from boar seminal plasma. Acta Biochim Pol 1999;46: 935-9.

[31] Bianchi PG, De Agostini A, Fournier J, Guidetti C, Tarozzi N, Bizzaro D, et al. Human cervical mucus can act in vitro as a selective barrier against spermatozoa carrying fragmented DNA and chromatin structural abnormalities. J Assist Reprod Genet 2004:21:97-102.

[32] Ellington JE, Broemeling LD, Broder SJ, Jones AE, Choker DA, Wright RW. Comparison of fresh and cryopreserved human sperm attachment to bovine oviduct (uterine tube) epithelial cells in vitro. J Androl 1999;20:492-9.

[33] Seli E, Sakkas D. Spermatozoal nuclear determinants of reproductive outcome: implications for ART. Hum Reprod Update 2005;11:337-49.

[34] Twigg J, Fulton N, Gomez E, Irvine DS, Aitken RJ. Analysis of the impact of intracellular reactive oxygen species generation on 
the structural and functional integrity of human spermatozoa: lipid peroxidation DNA fragmentation and effectiveness of antioxidants. Hum Reprod 1998;13:1429-36.

[35] Aitken RJ, Clarkson JS. Significance of reactive oxygen species and antioxidants in defining the efficacy of sperm preparation techniques. J Androl 1988;9:367-76.

[36] Wassarman PM, Jovine L, Qi H, Williams Z, Darie C, Litscher ES. Recent aspects of mammalian fertilization research. Mol Cell Endocrinol 2005;234:95-103.

[37] Suarez SS, Pacey AA. Sperm transport in the female reproductive tract. Hum Reprod Update 2006;12:23-37.
[38] Perry AC, Wakayama T, Kishikawa H, Kasai T, Okabe M, Toyoda Y, et al. Mammalian transgenesis by intracytoplasmic sperm injection. Science 1999;284:1180-3.

[39] Moreira PN, Pozueta J, Giraldo P, Gutierrez-Adan A, Montoliu L. Generation of yeast artificial chromosome transgenic mice by intracytoplasmic sperm injection. Methods Mol Biol 2006;349. $151-62$.

[40] Kurome M, Ueda H, Tomii R, Naruse K, Nagashima H. Production of transgenic-clone pigs by the combination of ICSImediated gene transfer with somatic cell nuclear transfer. Transgenic Res 2006;15:229-40. 